\title{
The Implementation of Insolvency Test on Debtors' Bankruptcy in Performing the Principle of Justice
}

\author{
Isis Ikhwansyah, Lambok Marisi Jakobus Sidabutar
}

Faculty of Law, Universitas Padjadjaran, Bandung, Indonesia. Email: ikhwansyahisis@gmail.com Faculty of Law, Universitas Padjadjaran, Bandung, Indonesia. Email: Lamboksidabutar2002@yahoo.com

\begin{tabular}{l} 
ARTICLE INFO \\
\hline Keywords: \\
bankruptcy; creditors; \\
debtor; insolvency test; \\
pinciple of justice. \\
How to cite: \\
Ikhwansyah, I., and \\
Sidabutar, LMJ. The \\
Implementation of \\
Insolvency Test on \\
Debtors' Bankruptcy in \\
Performing the Principle \\
of Justice. MEDIA \\
HUKUM, +62 274 \\
387656 (Ext. 220) \\
Article History: \\
Received: 11-04-2019 \\
Reviewed: 15-10-2019 \\
Revised: 28-12-2019 \\
Accepted: 30-12-2019 \\
\end{tabular}

\section{Introduction}

\begin{abstract}
Bankruptcy requirements as a legal basis for bankruptcy applications are only based on the burden of proof in a simple manner which results in the debtor being easily declared bankrupt by the court. This impedes the realization of the principle of justice that has been mandated in Law Number 37 of 2004 concerning Bankruptcy and Suspension of Debt Payment Obligations (SDPO). This article aims to analyze the basis of justice related to the bankruptcy of the debtor and the implementation of the bankruptcy test in relation to the request for bankruptcy submitted to the debtor. This study is a normative juridical research method that uses descriptive-analytic research. This study also uses library research to collect data and analysis data with qualitative juridical methods. The results show that the debtor's bankruptcy application did not apply the Bankruptcy test. It is believed that insolvency test on the debtor's bankruptcy petition is as a manifestation of the principle of justice that is in accordance with Pancasila by providing balanced protection among creditors, debtors and other stakeholders.
\end{abstract}

DOI: 10.18196/jmh.20190137

Copyright (02019 MEDIA HUKUM. All rights reserved.

The monetary crisis that hit Indonesia since mid-1997 has had a very unfavourable influence on Indonesian economic stability. ${ }^{1}$ The monetary crisis hit both Indonesian macro economy elements and the banking sector. In the macro economy, the crisis occurred in fiscal policy in the form of a depreciation in the Rupiah exchange rate. The

1 Asikin, Z. (2013). Hukum Kepailitan dan Penundaan Pembayaran Utang di Indonesia. Jakarta: Pustaka Reka Cipta, p. 10. 
exchange rate of the Indonesian Rupiah (IDR) to the US Dollar sharply weakened twice only in a relatively short time between January-February and June-July 1998. ${ }^{2}$

The fall of IDR exchange rate has, at minimum, had a negative impact on the national economy, including the occurrences of: a negative balance of payments due to a high debt exchange rates in foreign exchange as converted into IDR; as well as the capital deficit in companies that had already received bank credit because the value of their assets in IDR was insufficient anymore compared with the value of the IDR from foreign currency debt. ${ }^{3}$ The monetary crisis had caused various pressures for Indonesia, including to change its bankruptcy law. Bankruptcy is a general seizure of debtor's property either at the time of the bankruptcy statement or obtained during the bankruptcy proceeded for the benefit of all creditors, who at the time the debtor was declared bankrupt, conducted with the supervision of the authorities. ${ }^{4}$

Changes in bankruptcy law were implemented to provide a way out from financial difficulties and guarantee the fulfilment of the interests of creditor companies by the debtor. The changes were made through Government Regulations in Lieu of Law Number 1 of 1998 on Amendments to the Law on Bankruptcy. ${ }^{5}$ The Government Regulations in Lieu of Law Number 1 of 1998 was stipulated to be a law through Law Number 4 of 1998 on the Stipulation of Government Regulation in Lieu of Law Number 1 of 1998 on the Amendment of the Law on Bankruptcy to be a Law. The latest amendment is through Law Number 37 of 2004 on Bankruptcy and Suspension of Debt Payment Obligations (SDPO). ${ }^{6}$

Law Number 37 of 2004 has been used to date as a legal basis for resolving bankruptcy disputes in Indonesia based on several principles. One of the principles is the principle of justice. In bankruptcy, a principle of justice is a sense that the provisions on bankruptcy can satisfy the sense of justice for the stakeholders. This principle of justice is to prevent the occurrence of arbitrariness of the debtors who seek repayment of their respective bills from the debtor by ignoring other creditors. ${ }^{7}$

In its implementation, the Law Number 37 of 2004 has not been able to provide optimal legal protection for debtors. Debtors categorized as established companies with high solvency levels such as PT. Citra Jimbaran Indah Hotel, PT. Asuransi Jiwa Manulife Indonesia (PT. Manulife Indonesia Life Insurance), and PT. Telkomsel can be easily declared bankrupt by the court. It is a legal consequence that arises because of the simplicity of bankruptcy requirements in Law Number 37 of 2004 that is only proven in a simple manner, without considering the debtor's ability to fulfil his/her obligations to creditors.

2 White, B.T. (2005). The IMF and the Politics of Financial Globalization: From the Asian Crisis to a New International Financial Architecture? New York: Palgrave Macmillan, p. 139.

3 Gunadi. (2001). Restrukturisasi Perusahaan dalam Berbagai Bentuk dan Pemajakannya. Jakarta: Salemba Empat, p. 3.

4 Hartono, D.T. (2016). "Perlindungan Hukum Kreditor berdasarkan Undang-Undang Kepailitan". Jurnal Ilmu Hukum Legal Opinion, 4(1): 1-9.

5 Atmadjaja, D.I. and Anwar. (2012). “Kedudukan Menteri Keuangan dalam Kepailitan Perusahaan Asuransi". Media Hukum, 19(1): 12-26.

6 Sastrawidjaja, M.S. (2014). Hukum Kepailitan dan Penundaan Kewajiban Pembayaran Utang. Bandung: Alumni, p. 15.

7 Hartini, R. (2008). Hukum Kepailitan. Malang: UMM Press, p. 14. 
Insolvency is an inability to perform financial obligations fulfilment when it due as in business; or excess of liability compared to assets at a particular time. The condition when liabilities exceeds assets must occur within a reasonable period. ${ }^{8}$ Explanation of Article 57 Paragraph (1) of Law Number 37 of 2004 states that "insolvency" means the condition of being unable to pay. The situation of stopping to pay off debt due to inability to pay means that the debtor is in a difficult financial situation that causes the amount of the obligation to exceed the amount of the debtor's assets. ${ }^{9}$

Law Number 37 of 2004 does not regulate matters on the insolvency test. When in fact, the insolvency test is an essential step in the Law on Bankruptcy. The act of proofing is intended to ascertain the extent to which the debtor has the ability to fulfil his/her obligation to repay the debts to the creditors. The condition when the debtor is unable to pay should not be based solely on the assumptions constructed on legal presupposition. Instead, there should be evidence indicating that the debtor is actually in a state of insolvency or specific reasons that cause the debtor unable to perform his/her obligations to the creditors.

This absence of insolvency test in Law Number 37 of 2004 as the basis of the act of proofing for a debtor's bankruptcy petition has several consequences in legal issues, namely it is considered too easy for a debtor to be declared bankrupt by the court. It is indeed, not only detrimental to the debtor's business interest, but may also inflict losses to other parties related to the debtor's business. Besides, the absence of insolvency test in Law Number 37 of 2004 is deemed not in line with the principle of justice in the Bankruptcy law.

Therefore, the article describes the following research question: How is the implementation of the insolvency test of the debtor's bankruptcy petition in implementing the principle of justice? The goal is to provide equal protection among debtors, creditors and other stakeholders as the basis of judgment based on Pancasila.

\section{Method}

This article uses a normative juridical research method, namely a research that is used method to analyze legal norms contained in legislation and court decisions. In analyzing legal norm, the study uses a statutory and case approach.

The research specification in this study is descriptive analytical. The research aims to provide a detailed, systematic, and comprehensive description of the implementation of insolvency test on a debtor's bankruptcy petition. ${ }^{10}$ Data collection in this study was conducted through library research to obtain secondary data. This study uses qualitative juridical methods for data analysis.

Fuady, M. (2014). Hukum Pailit dalam Teori dan Praktik. Bandung: Citra Aditya Bakti, p. 127-128.

9 Hidayah, L.N. (2016). “Indikator Insolvensi sebagai Syarat Kepailitan menurut Hukum Kepailitan Indonesia". Jurnal Ilmu Hukum, 7(1): 134-144.

10 Soekanto, S. (2012). Pengantar Penelitian Hukum. Bandung: UI Press, p. 10. 


\section{Analysis and Results}

\subsection{A Debtor's Bankruptcy in the Perspective of Justice as Specified in Pancasila}

Bankruptcy has a vital role in the conduct of the global business activities. Bankruptcy plays a role in providing legal certainty in the settlement of debts and disputes among business actors by regulating the protection of the interests of every party. Hence, no one suffers any losses or disadvantageous nor takes advantage of others. With the Commercial Court decision of bankruptcy, the debtors, by law, lose their rights over the control and management of their assets included in the bankruptcy as of the date of the bankruptcy decision. Bankruptcy results in all debtors' assets and everything obtained during the bankruptcy is in generalized seizure from as the time the bankruptcy is decided. ${ }^{11}$ The management and settlement of liquidation shall be carried out by the Curator under the supervision of the Supervisory Judge with the primary objective of using the sold assets to repay all the debts of the bankrupt debtor proportionally (prorate parte) and in accordance with the creditor structure.

Several reasons that cause a debtor's bankruptcy: first, debtor's inability to pay the debt, hence, a bankrupt statement should be applied to repay debts that are due/matured. The debtor's failure is due to: financial distress because of a slowdown in the debtor's business; or in fact the assets of the debtor are insufficient to pay the obligations to the creditors. ${ }^{12}$ Second, the debtor's unwillingness to pay the debts for various reasons, including: the creditors have not yet completed their obligations (exceptio non adempleti contractus); the debtor considered that the debt transfer is invalid; the debtor deemed that the debt is not due; or a conduct of debt restructuring.

The purpose of bankruptcy is the division of debtor's assets by the Curator to all creditors by impartially observing the rights of each creditor. Thus, in the implementation of general seizure, confiscation and execution by an individual creditor must be avoided. The creditors must cooperate (concursus creditorum) in accordance with the provisions stipulated in Articles 1131 and 1132 of the Civil Code on the debtors' responsibility for their debts.

Bankruptcy is further execution of the provisions of Article 1131 and Article 1132 of the Civil Code. Bankruptcy is used as an alternative settlement obligation (debt) for debtor against the creditors being more effectively, efficient and proportionate. ${ }^{13}$ Both regulations provide certainty to creditors that all the debtor's existing and new assets will be present in the future (Article 1131 of the Civil Code) to be joint collateral for all creditors in a balanced or proportional manner, except for creditors with the preemptive right (Article 1132 of the Civil Code). Accordingly, Articles 1131 and 1132 of the Civil Code are general provisions (legi generali), whereas regulation on Bankruptcy regulates in a more specific scope the mechanism for settling debtor's debt payments that is fair and proportionate to all creditors. Therefore, justice is fundamental in the settlement of bankruptcy cases in the Commercial Court.

Justice is one of the most important objectives of law, in addition to legal certainty, usefulness and order. There are four values as important foundations for a good

11 Jono. (2008). Hukum Kepailitan. Jakarta: Sinar Grafika, p. 107.

12 Shubhan, M.H. (2008). Hukum Kepailitan, Prinsip, Norma dan Praktik di Peradilan. Jakarta: Kencana Prenada Media Group, p. 1.

13 Ishak. (2015). “Upaya Hukum Debitor terhadap Putusan Pailit”. Kanun Jurnal Ilmu Hukum, 17(65): 189215. 
human life, namely justice, truth, law and morals. But justice is the highest virtue, as stated by Plato: "Justices is the supreme virtue which harmonize all other virtues". ${ }^{14}$

The principle of justice in Law Number 37 of 2004 aims to avoid a dispute over the debtor's property by some creditors in collecting the debt employing dishonest acts or by an arbitrary action without considering other creditors. In the event of bankruptcy, it is expected that the debtor's assets can be used to pay the debts to the creditors fairly and equally.

It can be understood that the law-maker purposefully includes the principle of justice in the General Explanation of Law Number 37 of 2004 so that bankruptcy institution can protect the interests of each creditor in solving the debt payment settlement to the debtor. Hence, the principle of justice in the General Explanation of Law Number 37 of 2004 is in line with the concept of justice based on the Second Principle of Pancasila, namely "Fair and Civilized Humanity".

The Second Principle of the Pancasila, namely, "Fair and Civilized Humanity" contains the value of justice within individual relationships, through the realization of the rights and obligations of each individual, equal treatment for same individuals, and different treatments for different individuals, as well as providing a balance between rights and obligations for each individual. ${ }^{15}$ The arrangement of relations between debtors and creditors in resolving disputes on debt through bankruptcy institutions aims to guarantee the individual rights of all creditors to obtain the same rights in seeking payment for their debt.

The principle of justice in Law Number 37 of 2004 emphasizes the importance of guaranteeing creditors' rights. Hence, the norms on bankruptcy in Article 2 Paragraph (1) in conjunction with Article 8 Paragraph (4) of Law Number 37 of 2004 also become simple and easy. Every creditor, individually, may collect payments of their respective receivables from the debtor by filing a bankruptcy petition to the Commercial Court due to the straightforward requirements and an act of proofing. However, it is equally important and should also be a legal consideration in the bankruptcy petition of the debtor is the interest of the debtor itself, especially if the debtor is a business entity or a company.

The debtor as a business entity or company has relationships with the interests of other stakeholders, such as state interests, of tax revenues from the debtors that will be useful to finance programs to improve community development in supporting the improvement of the national economy; the interests of the workers who depend their lives on the debtors, consumers or debtor customers, suppliers that supply the business needs of the debtors, and so on. If a debtor who is a business entity or a company is declared bankrupt, the consequences will not only affect the debtor but will also create problems in the form of reducing of state revenues from the tax sector, termination of employment for the debtors' employees, broad impact on consumers or even economic dislocation.

The impact caused by the ease of bankruptcy petition for debtors, especially if the debtors is business entities or companies, should be prevented by expanding the

14 Amarini, I. (2018). “Mewujudkan Keadilan Sosial dalam Penyelesaian Sengketa di Pengadilan Administrasi". Media Hukum, 25(2): 162-170.

15 Pramono, N. \& Sularto. (2017). Hukum Kepailitan dan Keadilan Pancasila: Kajian Filsafat Hukum atas Kepailitan Badan Hukum Perseroan Terbatas di Indonesia. Yogyakarta: Andi, p. 211. 
meaning of the principle of justice in Law Number 37 of 2004. The principle of justice should not be interpreted in a narrow sense, i.e., only based on The Second Principle of Pancasila that is "Just and Civilized Humanity" in order to guarantee the individual rights of each creditor to obtain equal rights in seeking payment from the debtor. But, the principle of justice in a debtor bankruptcy should link "justice based on humanity" in the Second Principle with "social justice" in the Fifth Principle of Pancasila. It follows the coherent nature of Pancasila where each of the five Principles is interrelated and not contradictory.

The principle of "Social Justice for All Indonesian People" is a reference in achieving a fair and prosperous society. Social justice is realized for all Indonesian people. ${ }^{16}$ The value of justice contained in the "Social Justice for All Indonesian People" Principle should be realized in everyday life, in the context of social justice aimed at the wellbeing of all the people. ${ }^{17}$

Based on the Second and Fifth Principle of Pancasila, the debtor bankruptcy does not only accommodates the interests of the creditors, but also the benefits of the debtor, including considering the tax for the state, the interests of employees, the interests of consumers, the interests of suppliers, as well as the interests of investment security and certainty. It is because bankruptcy does have not only legal consequences for the debtor but also influences the interests of other parties related to the debtor's business activities.

A debtor's bankruptcy, in the perspective of justice that is based on the Second and the Fifth Principle of Pancasila implies that justice in Bankruptcy Law does not only meant to guarantee the individual rights of each creditor but also in a broader context, namely "Social Justice" to safeguard and protect the rights of debtors, including the interests of other parties related to the debtor's business activities. The implementation of this principle of justice in considering a debtor's bankruptcy is conducted by providing the opportunity for debtors to continue to carry out their business activities. Therefore, it is expected that the debtor will be able to repay the debts to all creditors. Thus, the debtor is protected from bankruptcy.

The principle of justice in bankruptcy means that starting from the consideration to the implementation of the bankruptcy of assets, it should pay attention to the interests of creditors and debtors, interests between creditors, and the interests of creditors and bankrupt debtors, all of which are carried out proportionately. ${ }^{18}$

\subsection{Implementation of Insolvency Test towards Debtor's Bankruptcy Petition}

Bankruptcy petition becomes debtors' financial means of escaping debt problems because they are no longer able to pay the debts to their creditors. In this state of inability to repay matured debts, if the debtors are aware, can be a step to apply for a bankruptcy decision to obtain a bankruptcy status, or the determination of bankruptcy

16 Tjiptabudy, J. (2010). “Kebijakan Pemerintah dalam Upaya Melestarikan Nilai-Nilai Pancasila di Era Reformasi". Jurnal Sasi, 16(3): 1-8.

17 Kaelan. (2010). Pendidikan Pancasila. Yogyakarta: Paradigma, p. 84.

18 Lontoh, R.A., Kailimang, D. and Ponto, B. (2001). Penyelesaian Utang-Piutang melalui Pailit atau Penundaan Kewajiban Pembayaran Utang. Bandung: Alumni, p. 137. 
status by the court if there is any evidence found that the debtor does not have the ability to repay debts that have already been matured and become payable. ${ }^{19}$

The requisite of bankruptcy as regulated in Article 2 Paragraph (1) of Law Number 37 of 2004 is indeed simple. Debtors who are still able to pay debts can be declared to bankrupt by the court of justice when the requisite of bankruptcy which only requires debt; one of the debts has enough time and can be billed; and the debtor has at least two or more creditors have normatively fulfilled. ${ }^{20}$

Referring to the provisions of Article 2 Paragraph (1) of Law Number 37 of 2004, debtor's application for bankruptcy decision must meet the following requirements:

a. The Debtor Has Two or More Creditors (concursus creditorum)

This requirement means that the debtor has a debt to two or more creditors. The debtors, in this case, are people who have debts due to agreements or laws that the repayment can be collected in court, while creditors are persons who have the credit/account receivables due to agreements or laws that can be collected in court.

b. Failing to Pay at least One Debt that Has Matured and Become Payable

The statement of failing to pay at least one debt that has matured and become payable means that the principal debt or interest that is not paid. However, in the explanation of Article 2 Paragraph (1) of Law Number 37 of 2004, it is stated that the obligation to pay debts that have matured and become payable because it has been agreed, due to the expediting of the transfer time as agreed, because of the imposition of penalties or fines by the authority, because of court decisions, arbitrators, or arbitral tribunals.

c. Either at the Request of the Debtor or the Request of One or More Creditors

Applications for bankruptcy can be submitted by the debtors themselves when they realize that they are no longer able to pay debts to the creditors. The request for debtor's bankruptcy can also be submitted by one or more creditors. Particularly for separatist and preferential creditors, they can file for debtor's bankruptcy without losing the preemptive right over collateral goods from the debtor's assets. In the event of a bankruptcy filed by a married debtor, then the application can only be submitted with the approval of the husband or wife unless there is no mixing of assets. In addition to being able to be filed by debtors and creditors, Article 2 of Law Number 37 of 2004 also provides the authority to submit debtor bankruptcy petition to the Commercial Court as proposed by the Office of the District Prosecutor, Bank Indonesia, Capital Market Supervisory Agency, or by the Minister of Finance.

A debtor's bankruptcy petition that requires failing to pay off at least one debt, becomes a highly important part. It is to ensure that even though some debts have been paid, but if all the debts have not been paid, then the debts can be used as a basis for applying for bankruptcy of the debtor.

A debtor's bankruptcy petition that requires failing to pay off at least one debt that has matured and become payable is not distinguished/differentiated whether the debtor

19 Yuhassarie, E. (2005). Undang-Undang Kepailitan dan Perkembangannya. Jakarta: Pusat Pengkajian Hukum, p. 55-56.

20 Slamet, S.R. (2009). “Kepailitan Suatu Solusi dalam Memaksimalkan Penagihan Piutang Kreditur”. Lex Jurnalica, 6(3): 195-204. 
simply does not want to pay his/her creditor for specific reasons, for example in the case of the creditor does not carry out the agreement as previously agreed upon, or instead whether the debtor is in a state of being unable to pay off his/her debts.

The vague description of a condition when debtors are truly incapable as one of the requirements for bankruptcy caused many debtors in the forms of business entities or companies to easily been declared bankrupt by the Court. It includes PT. Citra Jimbaran Indah Hotel, PT. Asuransi Jiwa Manulife Indonesia (PT. Manulife Indonesia Life Insurance), and PT. Telkomsel. These debtors are companies in Indonesia with a vast number of employees and consumers, have a high level of solvency and have good business prospects with estimated assets greater than their debts. However, these debtors can easily be declared bankrupt by the Court only because they fail to pay off in full one debt at the time of maturity and become payable'. Of course, it can cause a multiplier effect that disrupts the stability of the national economy.

The condition when the debtor is deemed easy to be declared bankrupt by the Court is a legal consequence of the fact that insolvency test is not stipulated in the Law Number 37 of 2004 on Bankruptcy and SDPO. All this time, the verification of bankruptcy applications has not been carried out through insolvency tests, but only based on simple evidence as stipulated in Article 8 Paragraph (4) of Law Number 37 of 2004, namely: "The petition for declaration of bankruptcy shall be granted if there are facts or circumstances summarily proving that the conditions for a declaration of bankruptcy as referred to in Article 2 Paragraph (1) have been met."

There are two factors to consider the need for insolvency tests as a model of proof in the bankruptcy process. Firstly, in several bankruptcy cases such as the bankruptcy case of PT. Citra Jimbaran Indah Hotel, PT. Asuransi Jiwa Manulife Indonesia (PT. Manulife Life Insurance Indonesia), and PT. Telkomsel, there is an indication showing that the debtor's position is fragile without any performance of an insolvency test. Although the business activities of the debtors were at the right level of solvency and had the ability to continue their business, the debtors were still easily declared bankrupt by the court. Secondly, a simple act of proofing as stipulated in Article 8 Paragraph (4) of the Law Number 37 of 2004 and SDPO caused debtor's bankruptcy petition to be easily granted by the Court, that was only based on facts or circumstances that are proven to be simple that the bankruptcy petition requirements have been fulfilled. It further confirms that granting a bankruptcy petition should require proof that is not too simple. Hence, the insolvency test is the right choice to replace a simple act of proofing to determine whether the debtor deserves to be declared bankrupt or not.

Based on the considerations above, bankruptcy law in Indonesia should implement a concept, namely: "An insolvency test to a debtor's bankruptcy petition". The idea of insolvency test aims to prove that the debtor has two or more creditors and is unable to pay off the debt to most creditors who have matured and become payable. Proof of bankruptcy petition is based on facts or circumstances that are proven utilizing insolvency test through 'going concern' audit assessment by the auditor from the public accountant that the requirements for being declared bankrupt have been fulfilled.

The scope of the implementation of insolvency tests to a debtor's bankruptcy petition includes the requirements and proof of bankruptcy. If previously the condition for 
bankruptcy petition as stipulated in Article 2 Paragraph (1) of the Law Number 37 of 2004 on Bankruptcy and SDPO is when "A debtor having two or more creditors and failing to pay at least one debt that has matured and became payable", the bankruptcy petition requirement is changed to "A debtor having two or more creditors and is incapable to pay off the debt to most creditors that have matured and become payable".

The phrase "incapable" is intended so that the bankruptcy conditions are stated explicitly and specifically that the debtor is genuinely in an insolvency condition to carry out the obligation to pay off the debts is not merely "not paying". Likewise, the phrase "most creditors" means that the debtor's inability to pay off his/her debts must be to most creditors, instead of just to one creditor. With these changes in bankruptcy conditions, debtors who are in solvency will not be too easy to be declared bankrupt and even the bankruptcy can be prevented as a form of legal protection for the interests of debtors and other stakeholders related to the debtor's business activities.

The act of proofing for bankruptcy petition cannot be proven based on facts or circumstances indicating that the bankruptcy requirements have been met as stipulated in Article 8 Paragraph (4) of Law Number 37 of 2004. The model of bankruptcy proofing of debtors who are genuinely incapable of carrying out their obligations is through a concept of insolvency test. Therefore, the provision of Article 8 Paragraph (4) of Law Number 37 of 2004 needs to be altered to "the petition for bankruptcy must be granted if there is a fact or circumstance that is proven in an insolvency test through an audit of 'going concern' by the auditor of a public accountant that the requirements for bankruptcy declaration have been fulfilled".

The 'going concern' audit assessment or opinion for a debtor will be an essential consideration factor for the auditor to issue a 'going concern' audit opinion. Companies with high-profit growth tend to have reasonable financial reports, thus, there will be greater potential to get a reasonable impression from the auditor. ${ }^{21}$ The debtor must not merely refuse to pay his/her debts, but objectively, the financial situation of the debtor audited by a public accountant must indicate that the debtor is in a state of inability to pay his/her debts. To determine whether the debtor's financial condition is in a state of inability to pay the debts, in other words, if the debtor has been in a state of insolvency, it must be determined objectively and independently. It can only be conducted based on a financial audit by an independent public accounting firm. ${ }^{22}$

Financial statements can easily indicate whether the debtor is eligible to be declared bankrupt or not. The consideration is if the results of the financial audit by the auditor suggest that the debtor is still solvent, then the debtor should not be declared bankrupt or prevented from bankruptcy by giving him/her the opportunity to continue the business activities in order to fulfil his/her obligations periodically to his/her creditors in the future. If the audit results from the auditor indicate otherwise i.e., that the debtor is in insolvency due to the continuous loss experienced in carrying out his/her business activities, and/or the amount of the asset is much smaller than the debts, then the debtor is eligible to be declared bankrupt.

21 Rahayu, S. (2009). “Faktor-Faktor yang Mempengaruhi Penerimaan Opini Audit Going Concern pada Perseroan Manufaktur Publik". Jurnal Kajian Akuntansi, 4(2): 145-155.

22 Sjahdeini, S.R. (2009). Hukum Kepailitan Memahami Undang-Undang No.37 Tahun 2004 tentang Kepailitan. Jakarta: PT. Pustaka Utama Grafiti, p. 39. 
The insolvency test is one of the most critical steps in the bankruptcy petition process to determine the debtor's prospects. It means that if the debtor is declared insolvency, then bankruptcy becomes the last resort for the settlement of debt disputes between the debtor and the creditors. Conversely, if the debtor is still in a state of solvency, he/she will be allowed to improve the financial condition through the Suspension of Debt Payment Obligation. This is an opportunity for the debtor who is in solvent aims to enable the debtor to fulfil the obligations to all future creditors because, in principle, the debtor is not "hopelessly in debt".

A debtor's bankruptcy petition should be directed towards debtors whose liabilities are higher than their assets, thus, the assets must be divided proportionally to the creditors. Debtors whose debts are more significant than their assets are better to be declared bankrupt so that the creditors get a maximum return on their debt. Based on this philosophy, debtors who are liable to be declared bankrupt should be those whose assets cannot fulfil the obligations to the creditors.

This implementation of insolvency test is to fulfil the aspect of philosophical justice, namely to bring out the necessary elements and conditions for a just community life. The aforementioned conditions are a status that can empower debtors when the amount of their assets is higher than their debts, and that their business ventures can still run smoothly and bring profit. Debtors with such status will create the necessary conditions for a truly just community life as they become something to depend on for the lives of many people. Not only for the business community in particular, the stakeholders of suppliers of goods and services, but also the community in general. Therefore, it is more desirable if only debtors who are genuinely in an insolvency situation who are declared bankrupt.

The objective of the implementation of the insolvency test in Law Number 37 of 2004 is to implement the principle of justice based on the Second Principle of Pancasila i.e., "Fair and Civilized Humanity" and the Fifth Principle, namely "Social Justice for All People of Indonesia". The bankruptcy law in Indonesia does not only guarantees legal protection for each creditor to secure their receivables, but also provides equal protection to debtors who are still in good faith in resolving their debts and to be able to carry on their business.

By implementing the insolvency test on a debtor's bankruptcy petition as a manifestation of the implementation of the principle of justice based on Pancasila, a philosophy of bankruptcy petition becomes one of the best ways out to escape from liabilities for a debtor. A debtor's bankruptcy petition should not be used as a means to collect debts from the debtors, by declaring them bankrupt, preferably, bankruptcy should be used as a means of finding a way out of the financial difficulties faced by the debtor in fulfilling the obligations that have been due to creditors. Nowadays, the most critical matter is how to increase loan repayments through a better system; not merely a liquidation case but a rehabilitation case. The required system is the one that can guarantee the return of loans to the creditors, instead of just bankrupting the debtor.

\section{Conclusion}

A debtor's bankruptcy should be based on the Second and the Fifth Principle of Pancasila, meaning that it does not only guarantee the individual rights of each creditor, but also guarantee and protect the rights of the debtor, including the interests 
of stakeholders related to the debtor's business activities, such as the interest of the country in the form of tax revenues, the interests of the employees, the interest of the consumers, the interests of the suppliers, as well as for the security and investment certainty.

In a debtor's bankruptcy petition, there is no regulation on an insolvency test, instead, it provides facts or circumstances that can be proven in a simple manner that the requirements for bankruptcy have been fulfilled. Law Number 37 of 2004 should regulate the implementation of the insolvency test on a debtor bankruptcy petition in the context of implementing the principle of justice based on the Second and the Fifth Principle of Pancasila.

The implementation of insolvency tests on a debtor bankruptcy aims to prove that the debtor has two or more creditors and is unable to pay at least one debt that has matured and became payable to most creditors. A debtor's bankruptcy petition is proven by an insolvency test through a 'going concern' audit opinion by an auditor from public accountants. Hence, only debtors who are truly in a state of inability to pay the debt who are eligible to be declared bankrupt.

\section{References}

Books:

Asikin, Z. (2013). Hukum Kepailitan dan Penundaan Pembayaran Utang di Indonesia. Jakarta: Pustaka Reka Cipta.

Fuady, M. (2014). Hukum Pailit dalam Teori dan Praktik. Bandung: Citra Aditya Bakti.

Gunadi. (2001). Restrukturisasi Perusahaan dalam Berbagai Bentuk dan Pemajakannya. Jakarta: Salemba Empat.

Hartini, R. (2008). Hukum Kepailitan. Malang: UMM Press.

Jono. (2008). Hukum Kepailitan. Jakarta: Sinar Grafika.

Kaelan. (2010). Pendidikan Pancasila. Yogyakarta: Paradigma.

Lontoh, R.A., et. al. (2001). Penyelesaian Utang-Piutang: Melalui Pailit atau Penundaan Kewajiban Pembayaran Utang. Bandung: Alumni.

Pramono, N \& Sularto. (2017). Hukum Kepailitan dan Keadilan Pancasila: Kajian Filsafat Hukum atas Kepailitan Badan Hukum Perseroan Terbatas di Indonesia. Yogyakarta: Andi.

Sastrawidjaja, M.S. (2014). Hukum Kepailitan dan Penundaan Kewajiban Pembayaran Utang. Bandung: Alumni.

Shubhan, M.H. (2008). Hukum Kepailitan, Prinsip, Norma dan Praktik di Peradilan. Jakarta: Kencana Prenada Media Group.

Sjahdeini, S.R. (2009). Hukum Kepailitan Memahami Undang-Undang No. 37 Tahun 2004 tentang Kepailitan. Jakarta: PT Pustaka Utama Grafiti.

Soekanto, S. (2012). Pengantar Penelitian Hukum. Bandung: UI Press.

White, B.T. (2005). The IMF and the Politics of Financial Globalization: From the Asian Crisis to a New International Financial Architecture? New York: Palgrave Macmillan. 
Yuhassarie, E. (2005). Undang-Undang Kepailitan dan Perkembangannya. Jakarta: Pusat Pengkajian Hukum.

\section{Journal Articles:}

Amarini, I. (2018). "Mewujudkan Keadilan Sosial dalam Penyelesaian Sengketa di Pengadilan Administrasi". Media Hukum, 25(2): 162-170.

Atmadjaja, D.I. \& Anwar. (2012). "Kedudukan Menteri Keuangan dalam Kepailitan Perusahaan Asuransi". Media Hukum, 19(1): 12-26.

Hartono, D.T. (2016). “Perlindungan Hukum Kreditor berdasarkan Undang-Undang Kepailitan". Jurnal Ilmu Hukum Legal Opinion, 4(1): 1-9.

Hidayah, L.N. (2016). “Indikator Insolvensi sebagai Syarat Kepailitan menurut Hukum Kepailitan Indonesia". Jurnal Ilmu Hukum, 7(1): 134-144.

Ishak. (2015). "Upaya Hukum Debitor terhadap Putusan Pailit". Kanun Jurnal Ilmu Hukum, 17(65): 189-215.

Rahayu, S. (2009). “Faktor-Faktor yang Mempengaruhi Penerimaan Opini Audit Going Concern pada Perseroan Manufaktur Publik". Jurnal Kajian Akuntansi, 4(2): 145155.

Slamet, S.R. (2009). "Kepailitan Suatu Solusi dalam Memaksimalkan Penagihan Piutang Kreditur". Lex Jurnalica, 6(3): 195-204.

Tjiptabudy, J. (2010). “Kebijakan Pemerintah dalam Upaya Melestarikan Nilai-Nilai Pancasila di Era Reformasi”. Jurnal Sasi, 16(3): 1-8. 